\title{
IS MORE PRECISE DATING OF PALEOINDIAN EXPANSION FEASIBLE?
}

\author{
Stuart J Fiedel \\ Louis Berger Group, 801 E. Main St., Suite 500, Richmond, Virginia 23219, USA. Corresponding author. \\ Email: sfiedel@louisberger.com. \\ Yaroslav V Kuzmin \\ Institute of Geology \& Mineralogy, Siberian Branch of the Russian Academy of Sciences, Koptyug Ave. 3, Novosibirsk \\ 630090, Russia.
}

\begin{abstract}
Recent efforts to precisely date the florescence of the Clovis culture in North America have been hampered by both practical and theoretical problems: 1) The era of Clovis expansion (about 11,200-10,700 BP or 13,200-12,700 cal BP) coincides with the gap between the anchored central European tree-ring sequence (back to 12,400 cal BP) and the floating Bølling-Allerød sequence; 2) Clovis seems to immediately precede the onset of the Younger Dryas (YD) stadial. The "black mats" of the US Southwest appear to mark the regional occurrence of this climatic downturn. However, the timing and means of long-distance propagation of this climatic event are not yet well understood. Greenland ice cores (GISP2, GRIP, and NGRIP) remain poorly synchronized, with a discrepancy of 100 to $250 \mathrm{yr}$ for the date of onset (as late as 12,700 cal BP, or as early as 12,950 cal BP); 3) The YD onset was accompanied by a rapid drop of radiocarbon ages from 11,000 to 10,600 BP in less than a century. The mechanism causing this was probably a change in overturning circulation in the North Atlantic. Do variable Clovis ages, often from what appear to be single-occupation contexts, reflect this "cliff" effect, slightly earlier minor reversals during the late Allerød, or simply the practical limitations of precision of the ${ }^{14} \mathrm{C}$ method? 4) Dates for Fishtail or Fell I sites (with fluted, stemmed points) in southern South America are statistically indistinguishable from Clovis dates in North America. Does this imply very rapid population expansion, diffusion of tool-making techniques through long-established local populations (as argued by Waters and Stafford 2007), or abnormally large interhemispheric ${ }^{14} \mathrm{C}$ offsets? 5) Are recent ostensibly high-precision collagen-derived dates for Paleoindian-associated fauna (e.g. horse and mammoth) reliable? Are interlaboratory blind tests of the new filtration processes necessary?
\end{abstract}

\section{EXACTLY HOW OLD IS CLOVIS?}

Despite recurrent claims that several ostensibly older archaeological sites have "broken the Clovis barrier," the Clovis culture, characterized by its beautiful fluted spearpoints, still represents the first unambiguously documented human occupation of North America (e.g. G Haynes 2002). Based upon conventional radiocarbon dates run in the 1960s, it became evident that the Clovis culture dated to about $11,500-10,800 \mathrm{BP}$. Because the anchored tree-ring sequence now extends only to $\sim 12,450$ cal BP, we still cannot yet really calibrate Clovis-associated dates; however, the dates can be corrected with some assurance to about 13,000 cal BP, by reference to climate events in ice cores, and to the floating Allerød tree ring series from central Europe (Kromer et al. 2004).

Based upon application of a rigorous "hygiene" to the available ${ }^{14} \mathrm{C}$ dates, Roosevelt et al. (2002) contended that the oldest Clovis dates were no earlier than 11,200 BP. Waters and Stafford (2007) have similarly reviewed the whole corpus of dates, added 10 new high-precision accelerator mass spectrometry (AMS) ${ }^{14} \mathrm{C}$ dates from T W Stafford's laboratory, and have subtracted another century, leaving the range of Clovis as about 11,100-10,800 BP. Of the few dates that appear older, most are imprecise conventional ${ }^{14} \mathrm{C}$ dates with large errors, run on loosely associated carbon (such as $11,630 \pm 400 \mathrm{BP}$ from Blackwater Draw and 11,470 $\pm 110 \mathrm{BP}$ from Lehner; see Waters and Stafford 2007, Supporting online material). Charcoal-derived ${ }^{14} \mathrm{C}$ dates of $11,540 \pm 110 \mathrm{BP}(\mathrm{AA}-5271)$ and $11,590 \pm 90$ BP (AA-5274) are reported from the Aubrey site in northern Texas (Ferring 1995, 2001). However, these were not from a defined hearth, and could represent either non-associated natural burning or an old-wood effect. Stafford (see Stafford and Waters 2007, Supporting online material, $\mathrm{p} 3$ ) has dismissed a ${ }^{14} \mathrm{C}$ date of $11,550 \pm 60 \mathrm{BP}$ (CAMS-35912) that he obtained for the Anzick infant (the only known Clovis burial) as erratic, because numerous additional dates on the

C 2010 by the Arizona Board of Regents on behalf of the University of Arizona Proceedings of the 20th International Radiocarbon Conference, edited by A J T Jull RADIOCARBON, Vol 52, Nr 2-3, 2010, p 337-345 
bones average about 10,750 BP. J E Morrow submitted 2 antler tools from the grave assemblage, and both were ${ }^{14} \mathrm{C}$ dated by Beta Analytic, Inc. to $11,040 \mathrm{BP}( \pm 40$ and \pm 60$)$. A date on the infant's rib was more recent, 10,780 $\pm 40 \mathrm{BP}$ (Morrow and Fiedel 2006).

The best case for a Clovis site much older than $\sim 11,100$ BP may be at the East Wenatchee site (Washington State) where a spectacular cache of giant bifaces was discovered. Three of these tools bore particles of Glacier Peak tephra adhering to their lower faces (Mehringer and Foit 1990). It seems that the points must have been deposited soon after the Glacier Peak volcano erupted. Based upon a rather small set of imprecise ${ }^{14} \mathrm{C}$ dates from pond sediments in northwestern North America, the eruption has been dated until very recently as around 11,200 BP (Foit et al. 1993). However, Kuehn et al. (2009) have now proposed redating to $\sim 11,600$ BP $(13,700-13,400$ cal BP). Of particular note is a spruce cone that lay immediately above the G tephra in the Van Wyck bog in Idaho; this has been AMS ${ }^{14} \mathrm{C}$ dated to $11,540 \pm 70 \mathrm{BP}$ (CAMS-19138) (Doerner and Carrara 1999). The span of time that may have elapsed between the eruption and the deposition of the East Wenatchee points cannot be reliably estimated, so the tephra, even if older than previously thought, offers only a terminus post quem for the Clovis tool cache. Given the absence of soil formation in the interim, however, it seems likely that the artifacts were laid on the tephra very soon after the eruption.

\section{WHY DO SOUTH AMERICAN PALEOINDIAN SITES SEEM SO EARLY?}

Accumulating genetic evidence from mtDNA and $\mathrm{Y}$ chromosome lineages (e.g. Zegura et al. 2004; Tamm et al. 2007) has only reinforced the long-held assumption, based upon other biological similarities including dental traits, that Native Americans' ancestors came across the Bering land bridge from Siberia about 14,000 cal BP. Not coincidentally, that is also the age of the oldest known habitation sites in central Alaska (Swan Point and Broken Mammoth; see e.g. Hoffecker and Elias 2007). Contrary speculations about a European origin and transatlantic migration of Paleoindians (Stanford and Bradley 2002; Bradley and Stanford 2004) do not warrant serious consideration. Given their northern Asian and Beringian origin, the geographic logic of expansion requires that Paleoindians colonized North America first, then pushed on through Central America into South America. The evident stylistic progression from classic Clovis points to the Fishtail or Fell I fluted points of Patagonia (typically stemmed and narrower at the base than the northern points) would seem to correlate nicely with this basic model (Morrow and Morrow 1999).

However, the ostensible style sequence, in fact, seems to have no temporal depth. Both Roosevelt et al. (2002) and Waters and Stafford (2007) correctly observe that the ${ }^{14} \mathrm{C}$ dates associated with "fishtail" points are equivalent to Clovis dates, for example: Piedra Museo, 11,000 \pm 65 BP (AA-27950) and 10,925 \pm 65 BP (OxA-8528); Tres Arroyos, 11,085 \pm 70 BP (OxA-9248); Cerro Tres Tetas, $10,915 \pm 65$ BP (AA-22233); Cueva Casa del Minero, 10,999 \pm 55 BP (AA-37207) and 10,967 \pm 55 BP (AA-37208); and Quebrada Santa Julia, 11,090 \pm 80 BP (Beta-215089), 11,060 \pm 80 BP (Beta215090), and 10,920 \pm 80 BP (Beta-194725) (see original sources in Faught 2008:675). Evidently, the makers of Fell I fishtail points had already reached the southern tip of South America by $\sim 11,000$ BP (Flegenheimer and Zarate 1997; Steele and Politis 2008). Roosevelt et al. (2002) and Waters and Stafford (2007) infer from this apparent contemporaneity that the South American Paleoindians cannot have been actual descendants of northern migrants; rather, some archaeologically invisible, previously dispersed earlier populations must have adopted the new lithic technology from the north. Given the absence of a coherent archaeological signature of this hypothetical indigenous population, that is not a satisfactory model (G Haynes et al. 2007). Humans who had successfully colonized a continent should have already possessed an adaptive and efficient lithic tool kit. We would be able to recognize it easily (unlike the randomly cracked and rounded stream pebbles that form most of 
the Monte Verde II "assemblage"; see Dillehay 1997; Fiedel 1999); also, there might have been some reluctance to adopt an untried new suite of tools, and the various local imitations of Clovis would be expected to display some regionally specific stylistic distinctions and persistent features of the precursor technology. But, what we actually see instead is an amazingly rapid spread of a uniform tool style from Central America all the way to the southern tip of South America (Tierra del Fuego). Rather than postulate an invisible, long-resident pre-Clovis population, it is more sensible to suggest that there is a very sparse record representing the expansion and growth of the colonizing Paleoindian population, over a period of about 2 centuries, from a founding macroband of about 200 Beringian emigrants to roughly 50,000-100,000 people in North America and about the same number in South America. As modeled mathematically by Hazelwood and Steele (2003), a rapid continental expansion of this order would appear effectively instantaneous, leaving no visible cline of ${ }^{14} \mathrm{C}$ dates to track the wave from its presumed northwestern source.

How, then, can we explain the equivalent ages of Clovis and Fishtail assemblages (Figure 1)? First, the Paleoindian hunters may simply have continued moving across the landscape very rapidly (Fiedel 2000, 2002, 2006a). It is often objected that, as they trekked southward, they would have encountered very different environments that would each have required a long period of re-adaptation. But, if they lived mainly by hunting big game (as their Beringian ancestors surely did), they would have continually encountered mammal species related or analogous to those they already knew (Kelly and Todd 1988): there were horses in Alberta and Tierra del Fuego; ground sloths in Arizona and Florida, and in Patagonia; mastodonts in New York; and gomphotheres in Chile. Second, the inter-hemispheric offset of ${ }^{14} \mathrm{C}$ in the terminal Pleistocene may have been significant. Between $\mathrm{AD} 950$ and 1850 , the ${ }^{14} \mathrm{C}$ offset between the hemispheres varied periodically, with values ranging from 8 to $80 \mathrm{yr}$ (McCormac et al. 2004). A comparison of ${ }^{14} \mathrm{C}$ dates from $\sim 12,500 \mathrm{cal} \mathrm{BP}$ from Argentina, Tasmania, and Venezuela suggests that the offset may have then have been on the order of 100-200 yr; that is, Paleoindian sites in the south that appear coeval with Clovis may actually be a century or two younger. However, the Argentine ${ }^{14} \mathrm{C}$ dates, derived from bulk samples of gyttja in lakes Huelmo and Mascardi (Hajdas et al. 2003), are not as reliable as ${ }^{14} \mathrm{C}$ dates on terrestrial plant macrofossils; so they must be regarded as merely suggestive.

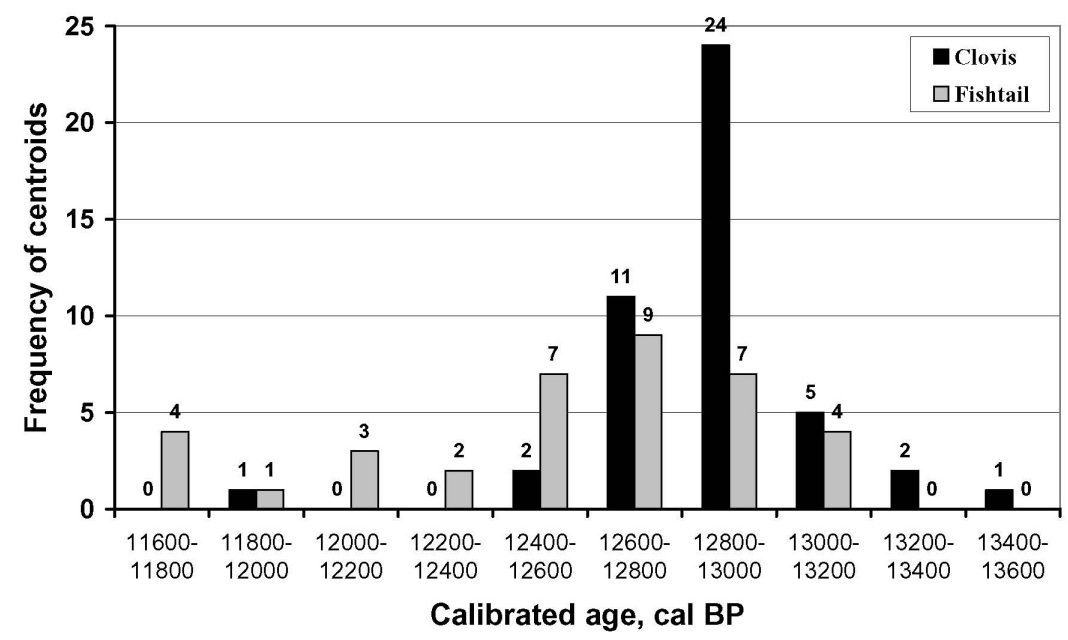

Figure 1 Chronological relationship between the Clovis and Fishtail complexes (occupation episodes counting after Fiedel and Kuzmin 2007 ; original ${ }^{14} \mathrm{C}$ dates are taken from Stafford and Waters 2007; Faught 2008). 
Although interhemispheric ${ }^{14} \mathrm{C}$ offsets may be involved, an alternative approach to this problem would focus solely on the plateau effect that is evident in the floating Allerød tree rings (Kromer et al. 2004). Clovis-era ${ }^{14} \mathrm{C}$ dates of about $11,100-10,950 \mathrm{BP}$ fall on this plateau. The same plateau appears in the dated sediments from Patagonian lakes (Hajdas et al. 2003) (Table 1). Unfortunately, these ${ }^{14} \mathrm{C}$ dates cannot yet be confidently translated into calendar time. The era of Clovis expansion (about 11,200-10,700 BP) coincides with the gap between the anchored central European tree-ring sequence (now extending back to $12,400 \mathrm{cal} \mathrm{BP}$ ) and the floating Bølling-Allerød sequence (Figure 2). Clovis expansion seems to have immediately preceded the abrupt onset of the Younger Dryas (YD) stadial. The "black mats" of the US Southwest appear to mark the regional occurrence of this climatic downturn (CV Haynes 2007, 2008). We will not address here the intriguing but improbable hypothesis that the mats also manifest a comet impact attested by magnetic spherules and nanodiamonds (Firestone et al. 2007; but see Paquay et al. 2009; Surovell et al. 2009; CV Haynes et al. 2010).

Table 1 Allerød-era ${ }^{14} \mathrm{C}$ inversion in Lake Mascardi sediment record (after Hajdas et al. 2003).

\begin{tabular}{lll}
\hline Depth $(\mathrm{cm})$ & ${ }^{14} \mathrm{C}$ date, BP & Cariaco calendar year equivalent, cal BP \\
\hline 783.4 & $10,480 \pm 180$ & 12,600 \\
789.4 & $10,900 \pm 110$ & $\sim 12,800$ \\
791.5 & $10,810 \pm 85$ & $\sim 12,900$ \\
796.5 & $10,960 \pm 85$ & $\sim 12,950$ (YD onset) \\
801.5 & $11,240 \pm 85$ & 13,000 \\
811.1 & {$[10,440 \pm 95]$ (rejected) } & \\
812.1 & $11,050 \pm 90$ & $\sim 13,100$ \\
813.5 & $10,930 \pm 80$ & $\sim 13,100$ \\
816 & $11,170 \pm 110$ & $\sim 13,150$ \\
\hline
\end{tabular}

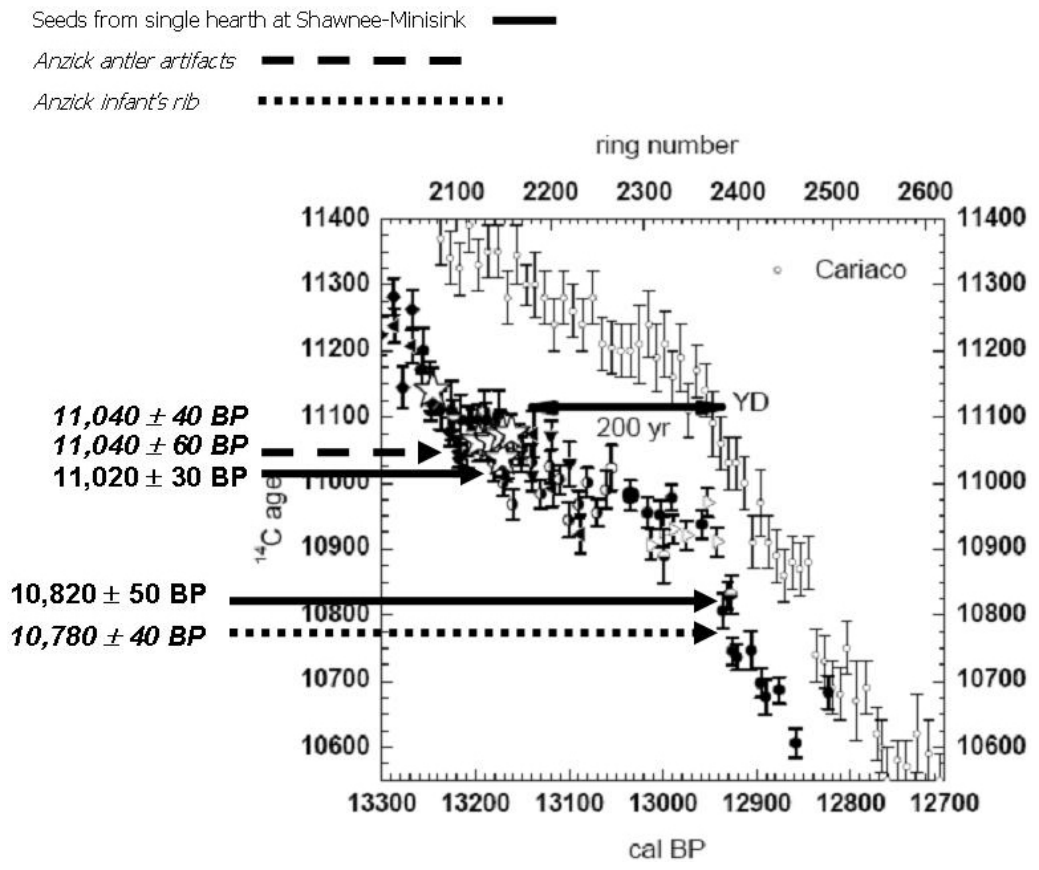

Figure 2 Position of the Shawnee-Minisink and Anzick ${ }^{14} \mathrm{C}$ dates relative to the Kromer et al. (2004) floating tree-ring sequence (modified from Kromer et al. 2004, Figure 2). 
The YD onset may not have been provoked by an impact, but the orthodox theory - disruption of North Atlantic circulation by rerouting of Lake Agassiz overflow through the St. Lawrence waterway-does not look very credible now, either (Lowell et al. 2005). The tempo and means of longdistance propagation of the YD climate signal beyond the North Atlantic region are not yet well understood. The onset date, marked by rapid deuterium and oxygen isotope shifts in the Greenland ice cores (GISP2, GRIP, and NGRIP) remains poorly synchronized (Southon 2002), with a discrepancy of up to $300 \mathrm{yr}$ [12,650 cal BP in GRIP; 12,850 in NGRIP (Steffensen et al. 2008); or 12,950 cal BP in GISP2].

The YD onset coincided with a rapid drop of ${ }^{14} \mathrm{C}$ ages from 11,000 to $10,600 \mathrm{BP}$ in less than a century (e.g. Broecker 2009). It is widely assumed that this jump or cliff was caused by a change in overturning circulation in the North Atlantic leading to reduced absorption of $\mathrm{CO}_{2}$ at the ocean surface (Goslar et al. 1995), although a minority view attributes it to a solar fluctuation (Renssen et al. 2000). This cliff seems to be a global phenomenon, seen in stratified sediments in Sweden, Alaska, Venezuela, and Argentina (Hajdas et al. 1998, 2003; Hughen 2000; Wohlfarth et al. 1998). Whatever the cause, it is a critical marker for absolute dating of Clovis, which falls on the preceding plateau (prior to 10,900 BP). Southon et al. (2007) has recently suggested that the cliff should be uncoupled from the YD onset. Based upon wiggle-matching of ${ }^{10} \mathrm{Be}$ in ice cores with ${ }^{14} \mathrm{C}$ fluctuations, Muscheler et al. (2008) contend that the recent end of the German floating tree-ring sequence lies at $12,500 \mathrm{cal} \mathrm{BP}$, and that the rings record a YD onset signal at $\sim 12,630 \mathrm{cal} \mathrm{BP}$. In view of the seemingly pan-hemispheric, isochronous warm peak just before the YD onset, seen in China (Wang et al. 2001), Venezuela (Hughen et al. 2000; Lea et al. 2003), and Europe and Greenland at 13,000 cal BP, it seems impossible to shift the European YD onset so drastically. Hua et al. (2009) have now wiggle-matched tree rings from Europe and Tasmania, to close the gap between the floating Late Glacial pine record and the anchored, absolute tree-ring timescale. They date the ${ }^{14} \mathrm{C}$ cliff to $\sim 12,760 \mathrm{cal} \mathrm{BP}$. If this revision is correct, the calendar age of the preceding plateau, and of Clovis, would have to shift accordingly from $12,950-13,200$ to $12,760-13,000$ cal BP.

Whatever may be the true age of the pre-YD plateau, the simplest solution to the conundrum of equivalent Clovis and Fishtail dates is to place some Clovis sites at the early end of the plateau, about 200 or $250 \mathrm{yr}$ before YD onset (i.e. $\sim 13,100 \mathrm{cal} \mathrm{BP}$ ), and the first Fell I sites at the cusp of the YD onset, at $\sim 12,900$ cal BP (Fiedel 2006b). This solution allows some 8 to 12 human generations for the migration from a presumed Clovis staging area in Texas to the tip of South America. If it turns out that the Aubrey and East Wenatchee dates of about 11,500-11,600 BP ( 13,500 cal BP) are correct, the time available for migration and population growth could be as much as $700 \mathrm{yr}$. Although we would all be more comfortable with this extended frame, the rapid population growth (doubling or tripling per generation) and long-distance movement necessary to fill the continents are still feasible within the more compressed chronology.

\section{ARE THERE PRACTICAL LIMITATIONS TO GREATER PRECISION?}

The Shawnee-Minisink site in Pennsylvania is now the most precisely ${ }^{14} \mathrm{C}$-dated Clovis site (Waters and Stafford 2007; Gingerich 2007). The AMS ${ }^{14} \mathrm{C}$ dates were run on samples of burnt hawthorn plum seeds from 2 hearths. There are hundreds of these seeds, which must have been simultaneously deposited over a very brief period of days or weeks. The dates are 10,820 \pm 50 BP (Beta-203865); $10,900 \pm 40$ BP (Beta-127162); 10,915 \pm 25 BP (UCIAMS-24865); 10,940 \pm 90 BP (Beta-101935); $10,970 \pm 50 \mathrm{BP}(\mathrm{OxA}-1731)$; and 11,020 $\pm 30 \mathrm{BP}$ (UCIAMS-24866) (see the youngest and the oldest ${ }^{14} \mathrm{C}$ values in Figure 2). Now, with $6{ }^{14} \mathrm{C}$ dates, the average is $10,935 \pm 15 \mathrm{BP}$, and theoretically

even greater precision could be achieved with additional values. However, the total span of these 
dates is from $\sim 10,800$ to $\sim 11,000$ BP (Figure 2), perhaps too broad considering the site's tight stratigraphic and planigraphic features.

Next, take into account these Paleoindian sites with multiple ${ }^{14} \mathrm{C}$ dates for the same samples or contexts (see original sources in Faught 2008): 1) Lange-Ferguson, 1 mammoth: 10,710 $\pm 130 \mathrm{BP}$ (UCIAMS-11344) and 11,110 \pm 40 BP (UCIAMS-11345) BP; 2) Dent, 1 mammoth: 11,065 \pm 35 BP (UCIAMS-11339) and 10,940 \pm 30 BP (UCIAMS-11340); 3) Anzick: a) antler rod 1, 11,040 \pm 60 BP (Beta-163832); b) antler rod 2, 11,040 $\pm 40 \mathrm{BP}$ (Beta-168967); c) infant rib, 10,780 $\pm 40 \mathrm{BP}$ (Beta-163833); and d) infant skull, 10,705 \pm 35 BP (CAMS-80538) (plus multiple dates from $10,240 \pm 120$ to $11,550 \pm 60 \mathrm{BP}$; see Waters and Stafford 2007, Supporting online material, p 8-9); and 4) Piedra Museo, Hippidion saldiasi, cut-marked distal humerus: $9950 \pm 95$ BP (AA-39362), $10,925 \pm 65$ BP (OxA-8528), and 10,675 \pm 55 BP (OxA-15870; ultrafiltrated). What does it mean, logically, when the dates' stated precision exceeds their accuracy?

We note the conclusion of Shukurov et al. (2009), who examined numerous European and Near Eastern ${ }^{14} \mathrm{C}$ dates for presumably short-lived archaeological events from about $9000-4000 \mathrm{cal} \mathrm{BP}$, that "the intrinsic accuracy of ${ }^{14} \mathrm{C}$ dating for the period is 100-200 yr regardless of the dating technique (AMS versus conventional)." For the period around 13,000 cal BP, we suggest that "intrinsic accuracy" might be about the same, or proportionally greater; see also N A Krenke and L D Sulerzhitsky's concept of "practicable accuracy" (e.g. Kuzmin and Orlova 1998:24).

\section{TESTING OF “KNOWN-AGE” BONE: A SUGGESTION}

Some of the most precise Paleoindian ${ }^{14} \mathrm{C}$ dates, with errors of only $20-30 \mathrm{yr}$, are now being reported for bone collagen samples (e.g. the example of the Dent mammoth). Are we really at the point where these dates are fully trustworthy? Are T W Stafford's XAD filters (e.g. Stafford et al. 1991) or Oxford's ultrafiltration method, which produced exaggerated ages for a while before the filter leaching problem was recognized (Higham et al. 2006), or any other laboratory's techniques, the most reliable? We strongly suggest that an interlaboratory blind test be conducted, and our candidate for this is the elk (or moose) from the Miesenheim IV site in the Rhineland (Germany), which was buried under Laacher See tephra at $\sim 11,060$ BP. Oxford's ORAU Laboratory previously ${ }^{14} \mathrm{C}$ dated the bones to $\sim 11,200$ BP (Hedges et al. 1993:149-50). The tephra was deposited during the Clovis era, $190 \mathrm{yr}$ before the YD onset. In this case, we at least know the precise upper limit of any future bone ${ }^{14} \mathrm{C}$ dates.

\section{CONCLUSION}

The pre-YD plateau may be an insuperable barrier to a precise chronology of Paleoindian migrations with a resolution better than $200 \mathrm{yr}$. The high-resolution coral ${ }^{14} \mathrm{C}$ dates with paired U-Th dates from Huon Peninsula (New Guinea) reported by Burr et al. (2004) appear to fall within this period, but they require marine reservoir correction, which may be erratic for that time. With more dates for tree rings in this interval and multiple high-precision ${ }^{14} \mathrm{C}$ values for extraordinary sites such as Shawnee-Minisink, perhaps we will reach a point where fine-scale wiggle-matching could be applied to the problem. We still need to determine exactly when Paleoindians arrived in the Americas, which routes they traversed, how long it took them to people both continents, and how they accomplished the extinction of the large-bodied native fauna, which were all extinct by $\sim 10,700 \mathrm{BP}$ in North America and 10,200 BP in South America (Fiedel 2009). If we can establish a precise chronology for the colonization process, there will be profound theoretical repercussions for ethnology, genetics, historical linguistics, demography, and ecology. 


\section{ACKNOWLEDGMENTS}

We thank Joseph Gingerich for sharing data from the recent excavations at Shawnee-Minisink, and 2 anonymous reviewers for useful suggestions and comments.

\section{REFERENCES}

Bradley B, Stanford D. 2004. The North Atlantic iceedge corridor: a possible Paleolithic route to the New World. World Archaeology 36(4):459-78.

Broecker W. 2009. The mysterious ${ }^{14} \mathrm{C}$ decline. Radiocarbon 51(1):109-19.

Burr GS, Galang C, Taylor FW, Gallup C, Edwards RL, Cutler K, Quirk B. 2004. Radiocarbon results from a 13-kyr coral from the Huon Peninsula, Papua New Guinea. Radiocarbon 36(3):1211-24.

Dillehay TD. 1997. Monte Verde, a Late Pleistocene Settlement in Chile. Volume 2. The Archaeological Context and Interpretation. Washington, DC: Smithsonian Institution Press. 1071 p.

Doerner JP, Carrara PE. 1999. Deglaciation and postglacial vegetation history of the West Mountains, westcentral Idaho, U.S.A. Arctic, Antarctic, and Alpine Research 31(3):303-11.

Faught MK. 2008. Archaeological roots of human diversity in the New World: a compilation of accurate and precise radiocarbon ages from earliest sites. American Antiquity 73(4):670-98.

Ferring CR. 1995. The Late Quaternary geology and archaeology of the Aubrey Clovis site, Texas: a preliminary report. In: Johnson E, editor. Ancient Peoples and Landscapes. Lubbock: Museum of Texas Technical University. p 273-81.

Ferring CR. 2001. The Archaeology and Paleoecology of the Aubrey Clovis Site (41DN479), Denton County, Texas. Unpublished report from Center for Environmental Archaeology, University of North Texas, to US Army Corps of Engineers, Fort Worth District, Texas.

Fiedel SJ. 1999. Artifact provenience at Monte Verde: confusion and contradictions. Scientific American Discovering Archaeology 1(6):1-12.

Fiedel SJ. 2000. The peopling of the New World: present evidence, new theories, and future directions. Journal of Archaeological Research 8(1):39-103.

Fiedel SJ. 2002. Initial human colonization of the Americas: an overview of the issues and the evidence. $R a-$ diocarbon 44(2):407-36.

Fiedel SJ. 2006a. Rapid Clovis colonization of the Americas: chronological evidence and archaeological analogues. In: Bonnichsen R, Lepper BT, Stanford D, Waters MW, editors. Paleoamerican Origins: Beyond Clovis. College Station: Texas A \& M University Press. p 97-102.

Fiedel SJ. 2006b. Points in time: establishing a precise hemispheric chronology for Paleoindian migrations. In: Morrow JE, Gnecco C, editors. Paleoindian Archaeology, a Hemispheric Perspective. Gainsville: University Press of Florida. p 21-43.
Fiedel SJ. 2009. Sudden deaths: the chronology of terminal Pleistocene megafaunal extinction. In: Haynes G, editor. American Megafaunal Extinctions at the End of the Pleistocene. New York: Springer-Verlag. p 21-38.

Fiedel SJ, Kuzmin YV. 2007. Radiocarbon date frequency as an index of intensity of Paleolithic occupation of Siberia: Did humans react predictably to climate oscillations? Radiocarbon 49(2):741-56.

Firestone RB, West A, Kennett JP, Becker L, Bunch TE, Revay ZS, Schultz PH, Belgya T, Kennett DJ, Erlandson JM, Dickenson OJ, Goodyear AC, Harris RS, Howard GA, Kloosterman JB, Lechler P, Mayewski PA, Montgomery J, Poreda R, Darrah T, Que Hee SS, Smith AR, Stich A, Topping W, Wittke JH, Wolbach WS. 2007. Evidence for an extraterrestrial impact 12,900 years ago that contributed to the megafaunal extinctions and the Younger Dryas cooling. Proceedings of the National Academy of Sciences of the USA 104(41):16,016-21.

Flegenheimer N, Zarate M. 1997. Considerations on radiocarbon and calibrated dates from Cerro La China and Cerro El Sombrero, Argentina. Current Research in the Pleistocene 14:27-8.

Foit Jr FF, Mehringer Jr PJ, Sheppard JC. 1993. Age, distribution, and stratigraphy of Glacier Peak tephra in eastern Washington and western Montana, United States. Canadian Journal of Earth Sciences 30(3): 535-52.

Gingerich JAM. 2007. Shawnee-Minisink Revisited: ReEvaluating the Paleoindian Occupation [unpublished MA thesis]. Laramie: University of Wyoming.

Goslar T, Arnold M, Bard E, Kuc T, Pazdur MF, RalskaJasiewiczowa M, Rozanski K, Tisnerat N, Walanus A, Wicik B, Wieckowski K. 1995. High concentration of atmospheric ${ }^{14} \mathrm{C}$ during the Younger Dryas cold episode. Nature 377(6548):414-7.

Hajdas I, Bonani G, Boden P, Peteet DM, Mann DH. 1998. Cold reversal on Kodiak Island, Alaska, correlated with the European Younger Dryas by using variations of atmospheric ${ }^{14} \mathrm{C}$ content. Geology 26(11): 1047-50.

Hajdas I, Bonani G, Moreno PI, Ariztegui D. 2003. Precise radiocarbon dating of Late-Glacial cooling in mid-latitude South America. Quaternary Research 59(1):70-8.

Haynes Jr CV. 2007. Appendix B. Nature and origin of the black mat, stratum F2. In: Haynes Jr CV, Huckell B, editors. Murray Springs: A Clovis Site with Multiple Activity Areas in the San Pedro Valley, Arizona. Tucson: University of Arizona Press. p 240-9.

Haynes Jr CV. 2008. Younger Dryas "black mats" and the 
Rancholabrean termination in North America. Proceedings of the National Academy of Sciences of the USA 105(18):6520-5.

Haynes Jr CV, Boerner J, Domanik K, Lauretta D, Ballenger J, Goreva J. 2010. The Murray Springs Clovis site, Pleistocene extinction, and the question of extraterrestrial impact. Proceedings of the National Academy of Sciences of the USA 107(9):4010-5.

Haynes G. 2002. The Early Settlement of North America: The Clovis Era. Cambridge: Cambridge University Press. 345 p.

Haynes G, Anderson D, Ferring R, Fiedel S, Grayson D, Haynes V, Holliday V, Huckell B, Kornfeld M, Meltzer D, Morrow J, Surovell T, Waguespack N, Wigand P, Yohe II R. 2007. Comment on "Redefining the age of Clovis: implications for the peopling of the Americas." Science 317(5836):320b.

Hazelwood L, Steele J. 2003. Colonizing new landscapes: archaeological detectability of the first phase. In Rockman M, Steele J, editors. Colonization of Unfamiliar Landscapes: The Archaeology of Adaptation. London: Routledge. p 203-21.

Hedges REM, Housley RA, Bronk Ramsey C, van Klinken GJ. 1993. Radiocarbon dates from the Oxford AMS system: Archaeometry datelist 16. Archaeometry 35(1):147-67.

Higham TFG, Jacobi RM, Bronk Ramsey C. 2006. AMS radiocarbon dating of ancient bone using ultrafiltration. Radiocarbon 48(2):179-95.

Hoffecker JF, Elias CA. 2007. Human Ecology of Beringia. New York: Columbia University Press. 290 p.

Hua Q, Barbett M, Fink D, Kaiser KF, Friedrich M, Kromer B, Levchenko VA, Zoppi U, Smith AM, Bertuch F. 2009. Atmospheric ${ }^{14} \mathrm{C}$ variations derived from tree rings during the early Younger Dryas. Quaternary Science Reviews 28(25-26):2982-90.

Hughen KA, Southon JR, Lehman SJ, Overpeck JT. 2000. Synchronous radiocarbon and climate shifts during the last deglaciation. Science 290(5498):19514.

Kelly R, Todd L. 1988. Coming into the country: early Paleoindian hunting and mobility. American Antiquity 53(2):231-44.

Kromer B, Friedrich M, Hughen KA, Kaiser F, Remmele S, Schaub M, Talamo S. 2004. Late Glacial ${ }^{14} \mathrm{C}$ ages from a floating, 1382-ring pine chronology. Radiocarbon 46(3):1203-9.

Kuehn SC, Froese DG, Carrara PE, Foit Jr FF, Pearce NJ, Rotheisler P. 2009. Major- and trace-element characterization, expanded distribution, and a new chronology for the latest Pleistocene Glacier Peak tephras in North America. Quaternary Research 71(2):201-16.

Kuzmin YV, Orlova LA. 1998. Radiocarbon chronology of the Siberian Paleolithic. Journal of World Prehistory 12(1): 1-53.

Lea DW, Pak DK, Peterson LC, Hughen KA. 2003. Synchroneity of tropical and high-latitude Atlantic tem- peratures over the Last Glacial termination. Science 301(5638):1361-4.

Lowell TV, Waterson N, Fisher T, Loope H, Glover K, Comer G, Hajdas I, Denton G, Schaefer J, Rinterknecht V, Broecker W, Teller J. 2005. Testing the Lake Agassiz meltwater trigger for the YoungerDryas. EOS Transactions, American Geophysical Union 86(40):365-73.

McCormac FG, Hogg AG, Blackwell PG, Buck CE, Higham TFG, Reimer PJ. 2004. SHCal04 Southern Hemisphere calibration, 0-11.0 cal kyr BP. Radiocarbon 46(3):1087-92.

Mehringer Jr PJ, Foit Jr FF. 1990. Volcanic ash dating of the Clovis cache at East Wenatchee, Washington. $\mathrm{Na}$ tional Geographic Research 6(4):495-503.

Morrow JE, Fiedel SJ. 2006. New radiocarbon dates for the Clovis component of the Anzick site (24PA506), Park County, Montana. In: Morrow JE, Gnecco C, editors. Paleoindian Archaeology, a Hemispheric Perspective. Gainsville: University Press of Florida. p 123-38.

Morrow JE, Morrow T. 1999. Geographic variation in fluted projectile points: a hemispheric perspective. American Antiquity 64(2):215-30.

Muscheler R, Kromer B, Björck S, Svensson A, Friedrich M, Kaiser KF, Southon J. 2008. Tree rings and ice cores reveal ${ }^{14} \mathrm{C}$ calibration uncertainties during the Younger Dryas Nature Geoscience 1(4):263-7.

Paquay FS, Goderis S, Ravizza G, Vanhaeck F, Boyd M, Surovell TA, Holliday, VT, Haynes Jr CV, Claeys P. 2009. Absence of geochemical evidence for an impact event at the Bølling-Allerød/Younger Dryas transition. Proceedings of the National Academy of Sciences of the USA 106(51):21,505-10.

Renssen H, van Geel B, van der Plicht J, Magny M. 2000. Reduced solar activity as a trigger for the start of the Younger Dryas? Quaternary International 68-71: 373-83.

Roosevelt AC, Douglas J, Brown L. 2002. The migrations and adaptations of the first Americans: Clovis and pre-Clovis viewed from South America. In: Jablonski NG, editor. The First Americans: The Pleistocene Colonization of the New World. San Francisco: California Academy of Sciences. p 159-236.

Shukurov A, Dolukhanov PM, Sokoloff DD. 2009. On the accuracy of radiocarbon dating for the Neolithic. Abstract \#5. 20th International Radiocarbon Conference, 29 May-5 June 2009, Kona, Hawaii, USA.

Southon JR. 2002. A first step to reconciling the GRIP and GISP2 ice-core chronologies, 0-14,500 yr B.P. Quaternary Research 57(1):32-7.

Southon J, Edwards L, Cheng H, Smith E, Hardt B, Hughen K. 2007. A new reconstruction for the onset of the Younger Dryas: evidence from speleothem, tree ring, and marine varve ${ }^{14} \mathrm{C}$ archives and Greenland ice core proxies. Abstract \#PP12A-03. American Geophysical Union Fall Meeting 2007. 
Stafford Jr TW, Hare PE, Currie L, Jull AJT, Donahue DJ. 1991. Accelerator radiocarbon dating at the molecular level. Journal of Archaeological Science 18(1):35-72.

Stanford D, Bradley B. 2002. Ocean trails and prairie paths? Thoughts about Clovis origins. In: Jablonski NG, editor. The First Americans: The Pleistocene Colonization of the New World. San Francisco: California Academy of Sciences. p 255-71.

Steele J, Politis G. 2008. AMS ${ }^{14} \mathrm{C}$ dating of early human occupation of southern South America. Journal of Archaeological Science 36(2):419-29.

Steffensen JP, Andersen KK, Bigler M, Clausen HB, Dahl-Jensen D, Fischer H, Goto-Azuma K, Hansson M, Johnsen SJ, Jouzel J, Masson-Delmotte V, Popp T, Rasmussen SO, Röthlisberger R, Ruth U, Stauffer B, Siggaard-Andersen M-L, Sveinbjörnsdóttir ÁE, Svensson A, White JWC. 2008. High-resolution Greenland ice core data show abrupt climate change happens in few years. Science 321(5889):680-4.

Surovell TA, Holliday VT, Gingerich JAM, Ketron C, Haynes Jr CV, Hilman I, Wagner DP, Johnson E, and Claeys P. 2009. An independent evaluation of the Younger Dryas extraterrestrial impact hypothesis. Proceedings of the National Academy of Sciences of the USA 106(43):18,155-8.

Tamm E, Kivisild T, Reidla M, Metspalu M, Smith DG, Mulligan CJ, Bravi CM, Rickards O, Martinez-Labarga C, Khusnutdinova EK, Fedorova SA, Golubenko MV, Stepanov VA, Gubina MA, Zhadanov SI, Ossipova LP, Damba L, Voevoda MI, Dipierri JE, Villems R, Malhi RS. 2007. Beringian standstill and spread of Native American founders. PLoS One 2(9): e829, doi:10.1371/journal.pone.0000829.

Wang YJ, Cheng H, Edwards RL, An ZS, Wu JY, Shen C-C, Dorale JA. 2001. A high-resolution absolutedated Late Pleistocene monsoon record from Hulu Cave, China. Science 294(5550):2345-8.

Waters MR, Stafford Jr TW. 2007. Redefining the age of Clovis: implications for the peopling of the Americas. Science 315(5815):1122-6.

Wohlfarth B, Björck S, Possnert G, Holmquist B. 1998. An 800-year long, radiocarbon-dated varve chronology from south-eastern Sweden. Boreas 27(4):24357.

Zegura SL, Karafet TM, Zhivotovsky LA, Hammer MF. 2004. High-resolution SNPs and microsatellite haplotypes point to a single, recent entry of Native American Y chromosomes into the Americas. Molecular Biology and Evolution 21(1):164-75. 